\title{
The Witness was a Spider: Acarology in Criminology
}

\author{
Aly H. Rasmy \\ National Research Centre, Dokki, Cairo, Egypt \\ e-Mail: aly_rasmy@hotmail.com
}

\begin{abstract}
Although the small size of mites makes them invisible to the naked eye and simply overlooked or discarded, but they are associated with humans during life and death. For example, the mite Demodex folliculorus Simon lives in the hair follicles of man at eyelashes, nipple, scalp, buttocks, mons venenis and ear wax (Breckenridge, 1953, and Goihman-Yahr, 1998). Also, Demodex brevis Akbulatova inhabits the sebaceous glands at the junction of nose and check and may be a cause of blepharitis through bacterial infection (English, 1969 and Nutting, 1991).
\end{abstract}

Thereafter, the author (2008) suggested that the aforementioned information provide evidences of physical abuse or neglect for people of advanced age or homeless people.

Moreover, spiders may be the causal agents of death such as the brown recluse and the widow group; all have potent venom, which are introduced when spiders bite.

Interestingly, once death takes place different mite species of forensic importance arrive as phoretic or carried by air current and colonize the corpse to feed on eggs and larvae of flies and enlarging mite population (Perotti \& Braig, 2010). Although, no studies concerning the detection of mites to the smell of death emanating from decayed remains of corpses was reported yet, but spiders and fungivorous mites arrive lastly to feed on dried tissues and other decomposing remains (Goff, 1993 and Rasmy, 2007).

On the basis of this scenario, Perotti and Braig (2010) reported that during the first 2-3 days after death, medical parameters are of most use to estimate the post-mortem interval. Thereafter, Demodex could survive for a further period up to 15 days after death (Wilson, 1844 and Rufli \& Mumcuoglu, 1981).

However, in an early study, Megnin (1894) was the first to use mites to estimate time of death in forensic investigations. He estimated the post-mortem interval of a new born baby in France based on the biology of the stored product mite, Tyrophagus longier (Gerg). The assembling of mites associated with the baby corpse, which was discovered inside chimney of the house, revealed that the state of decay dated back about two years. Accordingly, the innocence of a newly married couple, the current inhabitants of the house, was demonstrated.

Moreover, Leclercq and Varstraeten (1989) have provided data concerning the occurrence of spiders and mites on decomposing remains, and Goff (1992) documented the application of acarological data to the estimation of postmortem interval for a buried corpse on Oahu, Hawaii (Quoted from Goff, 1993).

Nowadays, in addition of telling the truth, the scope of forensic acarology goes further than the use of acarological data for estimation the postmortem interval or providing clues about suicide, homicide, accidental death or un-dental death and rapes. Also, spiders and mites can provide valuable information and evidences regarding drug trafficking. Interestingly, Starkeby (2005) reported that a brick of marijuana being shipped from Columbia to USA, while entering the border the drugs were seized. Laboratory investigations revealed that a unique species of spider recorded only in Columbia mountains, was noted associated with the drugs. Therefore, entomologist concluded that the drugs came from Columbia as it is the original point where the drugs were produced and packed before smuggling. 
However, many questions based in forensic acarology have yet to be answered.

In closing, forensic scientists and courts need only to listen to these silent agents and they will learn.

\section{REFERENCES}

Brickenridge, R.L. 1953.infestation of the skin with Demodex folliculorum. Am. J. Clin. Pathol., 23: 348352.

English, F.B. 1969. Demodex a cause of blepharetis in Australia. Medical Journal of Australia, 154: 121-125.

Goff, M.L. 1992. Proplems in estimation of postmortem interval resulting from wrapping of the corpse $-\mathrm{a}$ case study from Hawaii. J. Agric. Entomol., 9: 237.

Goff, M.L. 1993. Estimation of postmortem interval using arthropod development and successional patterns. Forensic Sci. Rev., 5: 81-94.

Goihman-Yahr, M. 1998. Demicidosis manifested on the external genitalia. Int. J. Dermatol., 37: 634-636.

Leclercq, M. and Verstraten, C.H. 1989. Entomologie et medicine legale. Datation de la mort. Acariens trouves sur de cadavers humains. Bull. Ann. Soc. Belg. Entomol., 124: 195.

Megnin, P. 1894. La fauna de cadavers. Ann. Hyg. Publ. Med. Leg., 33: 64-67.

Nuttingm W.B. 1991. Demodecosis, treatment and prevention. In: F. Dusbabek and V, Bukva (Eds): Modern Acarology, Academia: The Hague, Nederlands, 1: 307-317.

Perotti, M.A. and Braig, H.R. 2010. Acarology in criminological investigations: The human acarofauna during life and death. In: Forensic entomology: The utility of arthropods in legal investigation. J.H. Byrd and J.L. Custner, Eds. CRC Press, N.Y.

Rasmy, A.H. 2007. Forensic acarology: A new area of forensic investigation, Acarines, $2: 1-2$.

Rasmy, A.H. 2008. Mites and insects as indicators of physical abuse. Acarines, 2: 1-2.

Rufli, T. and Mumcuoglu, Y. 1981. The hair follicle mites Demodex folliculorum and Demodex brevis. Biology and medical importance. A review. Dermatologica, 162: 1-11.

Starkeby, M. 2005. Ultimate guide to forensic entomology: introduction Wep only essay. URL: http://folkuio.no/mostarke/forens_ent/ introduction.shtml. Accessed 5 Jan. 2004.

Wilson, E. 1844. Research into the structure and development of a newly discovered parasitic animalcule of the human skin - The Entozoon folliculorum. Philos. Trans. R. Soc. Lond., 134: 305-319. 